\title{
First case report of acute cholangitis secondary to Cronobacter sakazakii
}

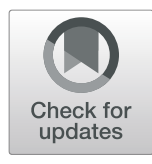

\author{
Syeda Sahra ${ }^{1 *} \mathbb{D}$, Abdullah Jahangir ${ }^{1}$, Neville Mobarakai ${ }^{1}$, Allison Glaser ${ }^{1}$, Ahmad Jahangir ${ }^{2}$ and \\ Muhammad Ans Sharif ${ }^{2}$
}

\begin{abstract}
Introduction: Cronobacter sakazakii is an opportunistic Gram-negative, rod-shaped bacterium which may be a causative agent of meningitis in premature infants and enterocolitis and bacteremia in neonates and adults. While there have been multiple cases of C. sakazakii infections, there have been no acute cholangitis cases reported in humans.

Case presentation: An 81-year-old male with a past medical history of basal cell carcinoma, alcoholic liver cirrhosis, transjugular intrahepatic portosystemic shunt procedure, complicated by staphylococcus bacteremia, pituitary tumor, glaucoma, and hypothyroidism presented to the emergency room with the complaint of diffuse and generalized 10/10 abdominal pain of 1 day's duration. There was a concern for pancreatitis, acute cholangitis, and possible cholecystitis, and the patient underwent a percutaneous cholecystostomy tube placement. Blood cultures from admission and biliary fluid cultures both grew C. sakazakii. The patient was treated with a carbapenem and clinically improved.

Conclusions: The case study described a patient with multiple medical comorbidities that presented with $C$. sakazakii bacteremia and cholangitis. While this bacterium has been implicated in other infections, we believe this is the first time the bacteria is being documented to have caused acute cholangitis.
\end{abstract}

Keywords: Cholangitis, Cholecystitis, Cronobacter sakazakii, Gallbladder infection

\section{Background}

C. sakazakii is responsible for life-threatening infections, including meningitis and brain abscesses with potentially permanent neurological sequelae for the neonatal population. The CC4 variant of Cronobacter has been associated with necrotizing enterocolitis as well. Urinary tract infections, septicemia, and lung and wound infections are reported in adults, particularly in those with underlying immunocompromising comorbidities. We present the first case of acute cholangitis in an elderly male where C. sakazakii was reported on the PCR assay of cultures from blood and biliary fluid. This is the first

\footnotetext{
* Correspondence: ssahra@northwell.edu

'Staten Island University Hospital, 475-Seaview Avenue, Staten Island, NY 10305, USA

Full list of author information is available at the end of the article
}

case of C. sakazakii in the medical literature where it caused cholangitis in an adult patient to the best of our knowledge. The patient responded well to therapy with a carbapenem. Infection with C. sakazakii should be considered in cholangitis in the elderly population with comorbidities not responsive to cephalosporins.

\section{Case presentation}

An 81-year-old male came to E.R. with the complaint of abdominal pain of 1 day's duration. His past medical records were significant for basal cell carcinoma, alcoholic liver cirrhosis with a history of an intrahepatic portosystemic shunt procedure, complicated by staphylococcus bacteremia, pituitary tumor, glaucoma, and hypothyroidism. The abdominal pain had been constant, non-radiating, diffuse, burning in nature,

(C) The Author(s). 2021 Open Access This article is licensed under a Creative Commons Attribution 4.0 International License, which permits use, sharing, adaptation, distribution and reproduction in any medium or format, as long as you give appropriate credit to the original author(s) and the source, provide a link to the Creative Commons licence, and indicate if changes were made. The images or other third party material in this article are included in the article's Creative Commons licence, unless indicated otherwise in a credit line to the material. If material is not included in the article's Creative Commons licence and your intended use is not permitted by statutory regulation or exceeds the permitted use, you will need to obtain permission directly from the copyright holder. To view a copy of this licence, visit http://creativecommons.org/licenses/by/4.0/ The Creative Commons Public Domain Dedication waiver (http://creativecommons.org/publicdomain/zero/1.0/) applies to the data made available in this article, unless otherwise stated in a credit line to the data. 
10/10 in intensity, and associated with chills. He denied any associated fevers, cough, nausea, vomiting, diarrhea, chest pain, headaches, shortness of breath, recent travels, or sick contacts.

On physical examination, his temperature was $98^{\circ} \mathrm{F}$, pulse $104 \mathrm{bpm}$, blood pressure $133 / 74 \mathrm{mmHg}$, respiratory rate 18 beats per minute, O2 saturation $99 \%$. An abdominal exam revealed an obese body habitus, distention, and periumbilical tenderness with a negative Murphy's sign.

Initial blood work showed normal leukocyte count white blood cells (WBC) $4.5 \mathrm{~K} / \mathrm{uL}$, Creatinine $1.2 \mathrm{mg} /$ $\mathrm{dL}$, elevated aspartate aminotransferase (A.S.T.) $62 \mathrm{U} /$ $\mathrm{L}$, elevated Lipase $451 \mathrm{u} / \mathrm{L}$, elevated Lactate $8.8 \mathrm{mmol} /$ $\mathrm{L}$, and normal serum levels of alanine aminotransferase (A.L.T.) $28 \mathrm{U} / \mathrm{L}$, Alkaline Phosphatase $99 \mathrm{U} / \mathrm{L}$, and total serum bilirubin $1.1 \mathrm{mg} / \mathrm{dL}$. The sonogram and C.T. scan of the abdomen revealed perihepatic ascites, nodular liver contour, cholelithiasis, and gallbladder sludge with mild gallbladder wall thickening up to 4 $\mathrm{mm}$ without any radiographic evidence of acute cholecystitis (Figs. 1 and 2).

The patient was not a surgical candidate due to his advanced age and multiple comorbidities, and a CT-guided percutaneous cholecystotomy was performed for drainage of biliary fluid by Interventional Radiology. The biliary fluid was sent for culture, and cefepime and metronidazole were started empirically.

On the second day of hospitalization, the periumbilical pain improved, but right upper quadrant tenderness increased, and Murphy's sign was elicited. The patient concurrently developed fever, leukocytosis $(16.5 \mathrm{k} / \mathrm{uL})$ with predominant neutrophilia (81\%), and worsening acute kidney injury. Blood specimens drawn on admission were positive for gram-negative rods, which speciated to C. sakazakii on PCR studies. The PCR assay was performed using BioFire FilmArray.

Body fluid samples underwent protein extraction, priming, and drying before matrix-assisted laser desorption/ionization-time of flight (MALDI-TOF) mass spectrometry was applied to the resultant intact cells and extracts from cells. Identification targets other than $C$. sakazakii were Enterococcus including vancomycinresistant Enterococcus, L. monocytogenes, coagulasenegative Staphylococcus, S. aureus, S. agalactiae (Group B), S. pneumoniae, S. pyogenes (Group A), A. baumannii, E. cloacae, E. coli, K. oxytoca, K. pneumoniae, Proteus sp., S. marcescens, $H$. influenzae, N. meningitidis, P. aeruginosa, C. albicans, C. glabrata, C. krusei, C. parapsilosis, C. tropicalis and the K. pneumoniae carbapenemase (KPC) resistant gene. Microflex L.T. and MADLI Biotyper by Bruker Daltonics, Germany was employed in our institutional laboratory for mass spectrometry measurements and microorganism identification. The same organism was found in the biliary drain culture, confirming acute cholangitis due to C. sakazakii complicated by bacteremia. Susceptibilities of C. sakazakii were obtained against 17 antibiotics (Figs. 3 and 4).

Antibiotic coverage was consequently expanded to IV meropenem. His clinical picture and blood work improved exponentially with a downtrend of leukocytes, lactate, lipase, bilirubin, and liver enzymes (Table 1). He was discharged home on hospital day seven on oral ciprofloxacin and metronidazole for 10 days and was

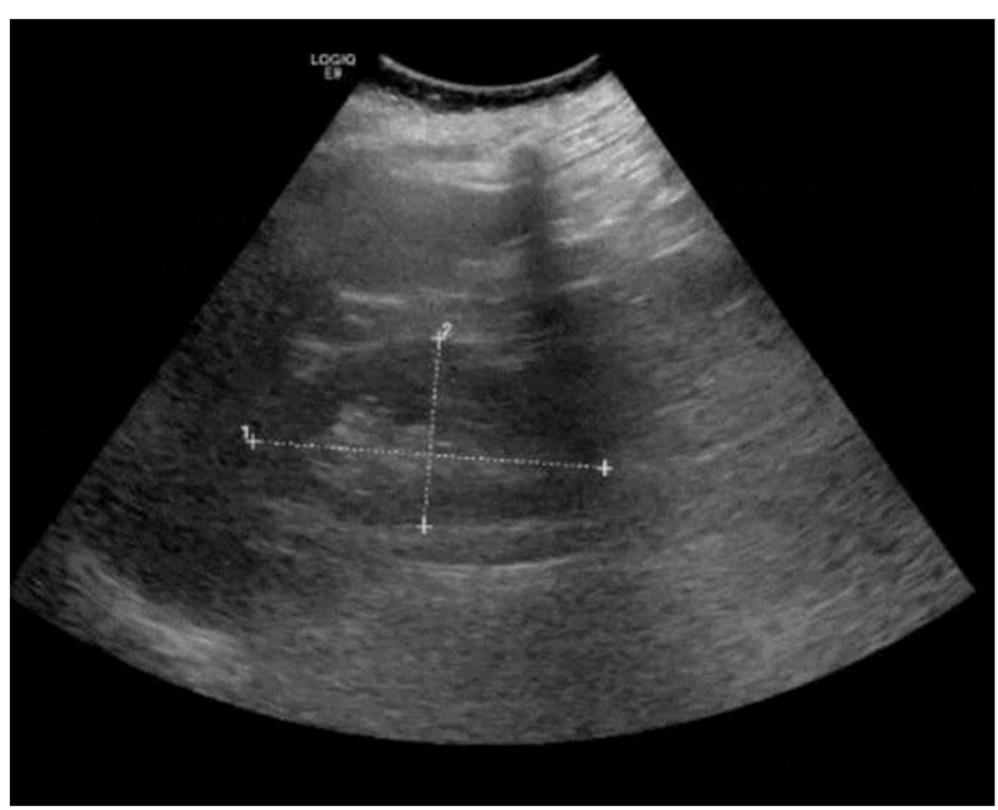

Fig. 1 Ultrasound on arrival showing biliary sludge and cholelithiasis without any radiographic evidence of acute cholecystitis 


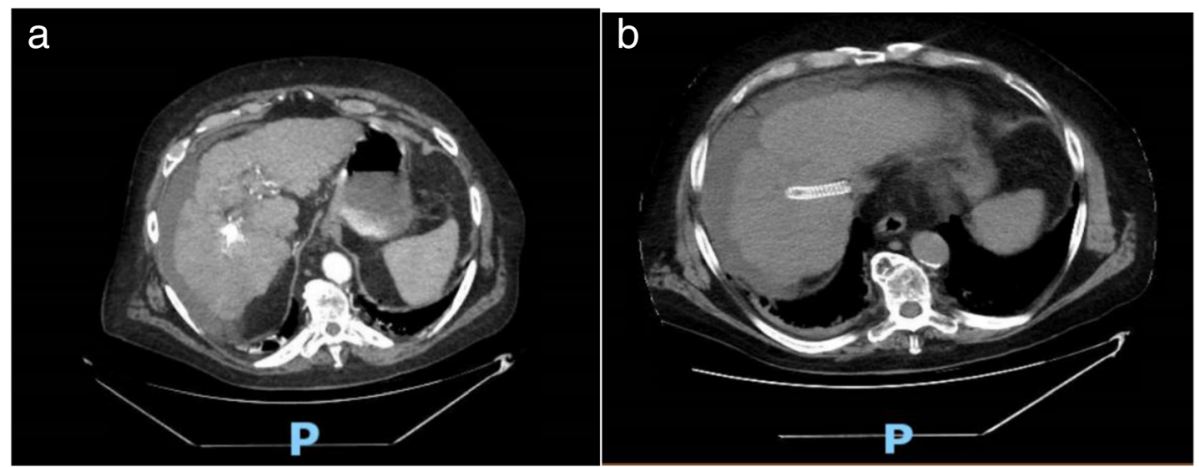

Fig. $\mathbf{2}$ a \& b C.T. scan abdomen showing nodular contour of liver, perihepatic ascites and TIPS from prior intervention

reported doing well on telephonic follow-up. The patient was later seen in outpatient clinics (Surgery and Infectious diseases) 2 weeks later. He was asymptomatic without any residual disease, and the biliary drain was removed successfully. The patient underwent an elective cholecystectomy a few weeks later with no complications.

\section{Discussion and conclusions}

C. sakazakii, previously called Enterobacter sakazakii, has been notorious since the 1980s for its fatal complications, including meningitis, hydrocephalus, and brain abscess in the neonatal population [1,2]. C. sakazakii infections, including urinary tract infections, bacteremia, osteomyelitis, splenic abscess, and wound infections,

\begin{tabular}{|c|c|c|}
\hline \multicolumn{2}{|l|}{$\begin{array}{l}\text { Organism } \\
\text { Cronobacter sakaza }\end{array}$} & Final \\
\hline \multicolumn{2}{|l|}{$\begin{array}{l}\text { Method Type } \\
\text { MIC }\end{array}$} & Final \\
\hline - Amikacin & $S<=16$ & Final \\
\hline - Ampicillin & $\mathrm{R}>16$ These ampicillin results predict results for amoxicillin & Final \\
\hline - Ampicillin/Sulbactam & $\begin{array}{l}S<=4 / 2 \text { Enterobacter, Citrobacter, and Serratia may develop } \\
\text { resistance during prolonged therapy (3-4 days) }\end{array}$ & Final \\
\hline - Aztreonam & $S<=4$ & Final \\
\hline - Cefazolin & $\begin{array}{l}S<=2 \text { Enterobacter, Citrobacter, and Serratia may develop } \\
\text { resistance during prolonged therapy ( } 3-4 \text { days) }\end{array}$ & Final \\
\hline - Cefepime & $\mathrm{S}<=2$ & Final \\
\hline - Cefoxitin & $S<=8$ & Final \\
\hline - Ceftriaxone & $\begin{array}{l}S<=1 \text { Enterobacter, Citrobacter, and Serratia may develop } \\
\text { resistance during prolonged therapy }\end{array}$ & Final \\
\hline - Ciprofloxacin & $S<=0.25$ & Final \\
\hline - Ertapenem & $S<=0.5$ & Final \\
\hline - Gentamicin & $S<=2$ & Final \\
\hline - Levofloxacin & $S<=0.5$ & Final \\
\hline - Meropenem & $S<=1$ & Final \\
\hline - Piperacillin/Tazobactam & $S<=8$ & Final \\
\hline - Tobramycin & $S<=2$ & Final \\
\hline $\begin{array}{l}\text { Trimetho prim/Sulfamethox } \\
\text { azole }\end{array}$ & $S<=0.5 / 9.5$ & Final \\
\hline
\end{tabular}

Fig. 3 Antibiotic sensitivities and susceptibilities for blood cultures growing Cronobacter sakazakii 


\begin{tabular}{|c|c|c|}
\hline \multicolumn{2}{|l|}{ Organism } & Final \\
\hline \multicolumn{2}{|c|}{$\begin{array}{l}\text { Method Type } \\
\text { MIC }\end{array}$} & Final \\
\hline - Amikacin & $S<=16$ & Final \\
\hline $\begin{array}{l}\text { - Amoxicillin/Clavulanic } \\
\text { Acid }\end{array}$ & $\mathrm{S}<=8 / 4$ & Final \\
\hline - Ampicillin & $\mathrm{R}>16$ These ampicillin results predict results for amoxicillin & Final \\
\hline - Ampicillin/Sulbactam & $\begin{array}{l}S<=4 / 2 \text { Enterobacter, Citrobacter, and Serratia may develop } \\
\text { resistance during prolonged therapy ( } 3-4 \text { days) }\end{array}$ & Final \\
\hline - Aztreonam & $S<=4$ & Final \\
\hline - Cefazolin & $\begin{array}{l}S<=2 \text { Enterobacter, Citrobacter, and Serratia may develop } \\
\text { resistance during prolonged therapy ( } 3-4 \text { days) }\end{array}$ & Final \\
\hline - Cefepime & $S<=2$ & Final \\
\hline - Cefoxitin & $\mathrm{S}<=8$ & Final \\
\hline - Ceftriaxone & $\begin{array}{l}S<=1 \text { Enterobacter, Citrobacter, and Serratia may develop } \\
\text { resistance during prolonged therapy }\end{array}$ & Final \\
\hline - Ciprofloxacin & $S<=0.25$ & Final \\
\hline - Ertapenem & $S<=0.5$ & Final \\
\hline - Gentamicin & $S<=2$ & Final \\
\hline - Levofloxacin & $S<=0.5$ & Final \\
\hline - Meropenem & $S<=1$ & Final \\
\hline - Piperacillin/Tazobactam & $S<=8$ & Final \\
\hline - Tobramycin & $S<=2$ & Final \\
\hline
\end{tabular}

Fig. 4 Antibiotic sensitivities and susceptibilities for cultures obtained from biliary fluid growing Cronobacter sakazakii

have been reported in the adult population, particularly in those with immunocompromising conditions [3-7]. A clinical study on stroke patients associated it with aspiration pneumonia as higher oral C. sakazakii inoculums were reported in patient cohorts [8].

Table 1 Trend of pertinent blood work through the hospitalization

\begin{tabular}{|c|c|c|c|c|c|}
\hline Blood work & Day 1 & Day 2 & Day 3 & Day 4 & $\begin{array}{l}\text { Discharge } \\
\text { blood work }\end{array}$ \\
\hline $\begin{array}{l}\text { WBC count } \\
\text { (k/uL) }\end{array}$ & 4.46 & 16 & & 10.59 & 5.11 \\
\hline $\begin{array}{l}\text { Hemoglobin } \\
\text { (g/dL) }\end{array}$ & 13.5 & 12.1 & 11.1 & 10.9 & 11.2 \\
\hline $\begin{array}{l}\text { Creatinine } \\
\text { (mg/dL) }\end{array}$ & 1.2 & & & 1.0 & 0.9 \\
\hline BUN (mg/dL) & 16 & & 36 & 29 & 14 \\
\hline $\begin{array}{l}\text { Bilirubin Total, } \\
\text { serum }(\mathrm{mg} / \mathrm{dL})\end{array}$ & 1.1 & & & 1.3 & 1.2 \\
\hline AST (U/L) & 621 & 18 & 25 & 17 & 40 \\
\hline ALT (U/L) & 28 & 49 & 81 & 6 & 31 \\
\hline $\begin{array}{l}\text { Lactate } \\
(\mathrm{mmol} / \mathrm{L})\end{array}$ & 88 & & 5 & 4. & 1.5 \\
\hline Lipase (U/L) & 15 & 44 & & & \\
\hline
\end{tabular}

C. sakazakii has been reported in the human gastrointestinal tract, domestic and nosocomial settings, laboratory samples, and food items [9-13]. Bacterial contamination of infant formula milk was thought accountable for outbreaks in the neonatal population [14-19]. Studies have been done and are in the process of establishing the true etiology and source of $C$. sakazakii, which previously had been a diagnostic challenge leading to lesser reporting [20].

The case presented is the first case of cholangitis secondary to C. sakazakii in humans. There was no radiographic evidence of cholecystitis. The source of this Gram-negative rod invasion could be from the patient's gastrointestinal flora. Basal cell carcinoma, liver cirrhosis, advanced age, and being on long-term steroid maintenance therapy could have contributed to immunosuppression and exponential growth of the opportunistic pathogen in the colon. Studies have reported C. sakazakii in pig gallbladder, hinting towards the gallbladder being a potential site of colonization and the risk of contracting C. sakazakii from consuming pork meat [21]. We could not rule out a dietary source in this patient. Sample contamination or infection with opportunistic gastrointestinal pathogens 
including Klebsiella, Acinetobacter, and E. coli were ruled out as $C$. sakazakii with similar antibiotic sensitivity was found on PCR studies for both blood biliary fluid. Besides, there was a dramatic response to optimum antibiotic treatment.

Carbapenems have been particularly efficient as $C$. sakazakii is resistant to ampicillin and the majority of cephalosporins [22]. Resistance to ampicillin was reported on antibiotic susceptibility testing for this organism as well. Ceftazidime, cephalothin, and cefotaxime were not added to the antibiotic sensitivity panel, which is a shortcoming in this case. The case raises the fact that $C$. sakazakii is a potential causative organism for gallbladder infections, particularly in elderly populations with underlying comorbidities. In conclusion, this case is significant in its clinical manifestation, causative pathogen, infection site, and treatment.

\section{Abbreviations}

E.R.: Emergency room; MALDI-TOF MS: Matrix-assisted laser desorption ionization-time of flight mass spectrometry

\section{Acknowledgments}

Clinical Research Programs SIUH is acknowledged for ethical review for the use of patient data.

\section{Authors' contributions}

Manuscript was written and literature review was obtained by S.S. and A.J. (1). A.G. and N.M. took care of the patient and contributed to the manuscript writing and editing. M.A.S. and A.J. (2) contributing to manuscript writing and revisions. All authors have read and approved the final manuscript.

\section{Funding}

No funding was obtained from any organization or personnel during any stage of manuscript writing or submission.

\section{Availability of data and materials}

The datasets used and/or analyzed during the current case reports are available from the corresponding author on reasonable request.

\section{Declarations}

\section{Ethics approval and consent to participate}

The case report and manuscript were reviewed with Research Department and Ethics Committee. No experimental intervention was performed, and any specification of guidelines, legislations, or permissions were not required.

\section{Consent for publication}

The patient and family were contacted during the hospital stay and after discharge. Written consent was obtained to use patient data, images, and blood work to publish the case for purely educational and research purposes, to which the patient and family agreed. Non identifying information usage was explained. A copy of the written consent is available for review by the Editor-in-Chief of this journal.

\section{Competing interests}

No competing financial or personal interests are involved for all the authors.

\section{Author details}

${ }^{1}$ Staten Island University Hospital, 475-Seaview Avenue, Staten Island, NY 10305, USA. ${ }^{2}$ King Edward Medical University, Lahore 54000, Pakistan.
Received: 27 October 2020 Accepted: 17 May 2021

Published online: 27 May 2021

\section{References}

1. Chaves CEV, Brandão MLL, Lacerda MLGG, Rocha CABC, Leone de Oliveira SMV, Parpinelli TC, et al. Fatal cronobacter sakazakii sequence type 494 meningitis in a newborn, Brazil. Emerg Infect Dis. 2018;24(10):1948-50. https://doi.org/10.3201/eid2410.180373

2. Burdette $\mathrm{JH}$, Santos $\mathrm{C}$. Enterobacter sakazakii brain abscess in the neonate: the importance of neuroradiologic imaging. Pediatr Radiol. 2000;30(1):33-4. https://doi.org/10.1007/s002470050009.

3. Alsonosi A, Hariri S, Kajsík M, Oriešková M, Hanulík V, Röderová M, et al. The speciation and genotyping of Cronobacter isolates from hospitalised patients. Eur J Clin Microbiol Infect Dis. 2015;34(10):1979-88. https://doi. org/10.1007/s10096-015-2440-8.

4. Lai KK. Enterobacter sakazakii infections among neonates, infants, children, and adults. Case reports and a review of the literature. Medicine (Baltimore). 2001;80(2):113-22. https://doi.org/10.1097/00005792-200103000-00004.

5. Healy B, Cooney S, O'Brien S, Iversen C, Whyte P, Nally J, et al. Cronobacter (Enterobacter sakazakii): an opportunistic foodborne pathogen. Foodborne Pathog Dis. 2010;7(4):339-50. https://doi.org/10.1089/fpd.2009.0379.

6. Hawkins RE, Lissner CR, Sanford JP. Enterobacter sakazakii bacteremia in an adult. South Med J. 1991;84(6):793-5. https://doi.org/10.1097/00007611-1991 06000-00033.

7. Dennison SK, Morris J. Multiresistant Enterobacter sakazakii wound infection in an adult. Infect Med. 2002;19:533-5.

8. Gosney MA, Martin MV, Wright AE, Gallagher M. Enterobacter sakazakii in the mouths of stroke patients and its association with aspiration pneumonia. Eur J Intern Med. 2006;17(3):185-8. https://doi.org/10.1016/j. ejim.2005.11.010.

9. Kandhai MC, Reij MW, Gorris LGM, Guillaume-Gentil O, van Schothorst M. Occurrence of Enterobacter sakazakii in food production environments and households. Lancet. 2004;363(9402):39-40. https://doi.org/10.1016/S01406736(03)15169-0.

10. Kandhai $\mathrm{MC}$, et al. A new protocol for the detection of Enterobacter sakazakii applied to environmental samples. J Food Prot. 2004;67(6):1267-70. https://doi.org/10.4315/0362-028X-67.6.1267.

11. Lehner A, Stephan R. Microbiological, epidemiological, and food safety aspects of Enterobacter sakazakii. J Food Prot. 2004;67(12):2850-7. https:// doi.org/10.4315/0362-028X-67.12.2850.

12. Beuchat LR, Kim H, Gurtler JB, Lin LC, Ryu JH, Richards GM. Cronobacter sakazakii in foods and factors affecting its survival, growth, and inactivation. Int J Food Microbiol. 2009;136(2):204-13. https://doi.org/10.1016/j. ijfoodmicro.2009.02.029.

13. Friedemann M. Enterobacter sakazakii in food and beverages (other than infant formula and milk powder). Int J Food Microbiol. 2007;116(1):1-10. https://doi.org/10.1016/j.ijfoodmicro.2006.12.018

14. van Acker J, de Smet F, Muyldermans G, Bougatef A, Naessens A, Lauwers S. Outbreak of necrotizing enterocolitis associated with Enterobacter sakazakii in powdered milk formula. J Clin Microbiol. 2001:39(1):293-7. https://doi. org/10.1128/JCM.39.1.293-297.2001

15. From the Centers for Disease Control and Prevention. Enterobacter sakazakil infections associated with the use of powdered infant formula--Tennessee, 2001. Jama. 2002;287(17):2204-5.

16. Iversen C, Forsythe S. Risk profile of Enterobacter sakazakii, an emergent pathogen associated with infant milk formula. Trends Food Sci Technol. 2003;14(11):443-54. https://doi.org/10.1016/S0924-2244(03)00155-9.

17. Forsythe SJ. Updates on the Cronobacter genus. Annu Rev Food Sci Technol. 2018;9(1):23-44. https://doi.org/10.1146/annurev-food-030117012246.

18. Chenu JW, Cox JM. Cronobacter ('Enterobacter sakazakii'): current status and future prospects. Lett Appl Microbiol. 2009;49(2):153-9. https://doi.org/1 0.1111/j.1472-765X.2009.02651.X.

19. Drudy D, Mullane NR, Quinn T, Wall PG, Fanning S. Enterobacter sakazakii: an emerging pathogen in powdered infant formula. Clin Infect Dis. 2006; 42(7):996-1002. https://doi.org/10.1086/501019.

20. Lepuschitz S, Ruppitsch W, Pekard-Amenitsch S, Forsythe SJ, Cormican M, Mach RL, et al. Multicenter study of cronobacter sakazakii infections in humans, Europe, 2017. Emerg Infect Dis. 2019;25(3):515-22. https://doi.org/1 $0.3201 /$ eid2503.181652. 
21. Evangelopoulou G, et al. Isolation and antimicrobial testing of aeromonas spp., citrobacter spp., cronobacter spp., enterobacter spp., escherichia spp. klebsiella spp., and trabulsiella spp. from the gallbladder of pigs. Pol J Microbiol. 2015;64(2):185-8. https://doi.org/10.33073/pjm-2015-028.

22. Holý $\mathrm{O}$, et al. Molecular characterization of cronobacter sakazakii strains isolated from powdered milk. Foods. 2020;10(1):20.

\section{Publisher's Note}

Springer Nature remains neutral with regard to jurisdictional claims in published maps and institutional affiliations.

Ready to submit your research? Choose BMC and benefit from:

- fast, convenient online submission

- thorough peer review by experienced researchers in your field

- rapid publication on acceptance

- support for research data, including large and complex data types

- gold Open Access which fosters wider collaboration and increased citations

- maximum visibility for your research: over $100 \mathrm{M}$ website views per year

At $\mathrm{BMC}$, research is always in progress.

Learn more biomedcentral.com/submissions 